\title{
Civil Society and Local Development
}

\author{
Henry Veltmeyer*
}

\section{Introduction}

The idea of civil society has achieved prominence in political and development discourse over the past two decades, particularly in connection with successive waves of democratization, beginning in Latin America and Eastern Europe, and spreading across the developing world. In normative terms, civil society has been widely seen as a crucial agent for limiting authoritarian government, empowering a popular movement, reducing the socially atomizing and unsettling effects of market forces, enforcing political accountability, and improving the quality and inclusiveness of governance, a term that denotes a particular set of interactions between civil society and governments ${ }^{1}$.

Reconsideration of the limits of government intervention in economic affairs, and a related neoconservative attack on the welfare-and developmental-state, have also led to an increased awareness of the potential role of civic organisations in the provision of public goods and social services, either separately or in some kind of 'synergistic' relationship with state institutions. Indeed it is possible to view the turn towards civil society in the provision of hitherto public goods and services as a form of privatization: turning over the economy to the 'private sector' (profit-oriented or capitalist enterprises) and responsibility for economic and political development to 'civil society' (an amalgam of social organisations found between the family and the state) $)^{2}$.

Recourse to the notion of civil society, and the construction of a civil society discourse, take different forms. In fact there are three different traditions in the use of the term, each associated with a particular conception of civil society (in regard to which organisations are included and excluded), a particular analytical use and a particular ideology.

One of these traditions can be labelled liberal ${ }^{3}$, associated with a mainstream form of political science and economics in which the spheres of politics and economics are treated as analytically distinct systems, is fundamentally concerned with and focuses on what we might term 'political development' - establishing a participatory form of politics and 'good 'i.e. 'democratic' governance. Here civil society is conceived of in essentially political terms, rooted in the Anglo-American tradition of liberal-democratic theory that identifies civic institutions and political activity as an essential component of political society based on the principles of citizenship, rights, democratic representation and the rule of law. On the ideological spectrum (left, centre, right) liberals see civil society as a countervailing force against an unresponsive, corrupt state and exploitative corporations that disregard environmental issues and human rights abuses (KAMAT, 2003).

The second tradition, rooted in a more sociological view of the state-society relation and the ideas of Antonio Gramsci, is similarly concerned with the form of politics but sees civil society as a repository of diverse forms of popular resistance to government policies, and the basis of a 'counter-hegemonic' bloc of social forces engaged in a process of contesting state and other forms of class power. It is based on what might be termed a radical ideology-a shared belief in the need for radical change, civil society is seen as a repository of the forces of resistance and opposition, forces than can be mobilized into a counter-hegemonic bloc (MORTON, 2004).

The third tradition is associated with the project of international cooperation for development; In this tradition civil society is viewed as an array of social organisations representing 'stakeholders' in a process of economic development, a strategic partner in the

\footnotetext{
* St. Mary's University - Canadá.
} 
war against global poverty waged by the World Bank and other international development associations and agencies. In this context, civil society is viewed as na agency for bringing about a participatory and empowering form of development-na organisational means of transforming the new development paradigm into practice. Proponents of this conception of civil society generally share a liberal ideology in terms seeing in civil society the beneficial effects of globalization for the development of democracy and economic progress (CHAN, 2001). Conservatives in this context tend to view NGOs as 'false saviours of international development' (KAMAT, 2003).

The purpose of this paper is to deconstruct elements of this civil society discourse, disclosing the associated or underlying dynamics. The point is that each form of civil society discourse can be understood, and analysed, at the level of theory, ideology and politics. To deconstruct civil society discourse in these terms we will, first of all, review the origins and contemporary uses of the concept 'civil society'. We then turn towards the development dynamics associated with the contemporary discourse on civil society.

This discourse is of two types, one associated with the dynamics of political development and the search for forms of 'democratic governance', the other with the dynamics of economic and social development-the search for alternative forms of development based on a new paradigm that are initiated from below and within civil society', that is socially inclusive, equitable, participatory and empowering. The chapter ends with a brief review of the role of different types of civil society organisations in the development process. The central focus of this review is on nongovernmental organisations and social movements, elements of civil society conceptualised as agencies of antiglobalization-repositories of the forces of opposition and resistance against the system of global capitalism in its dominant neoliberal form.

\section{Civil Society: The itinerary of a concept}

Definitions of 'civil society' are bewilderingly diverse, rooted in alternative social and political philosophies that are hard to reconcile. However, for our purpose it is advisable to come to some general agreement about what is meant by it, what it means in the particular discourse in which it might be embedded.

One definition is that of an intermediate realm situated between state and household, populated by organized groups or associations which are separate from the state, enjoy some autonomy in relations with the state, and are formed voluntarily by members of society to protect or extend their interests, values or identities ${ }^{4}$.

This definition excludes most highly informal associations of the personal network kind, as well as families or households-since these operate in the private sphere. Civil society, by contrast, operates in the public, albeit non-state, sphere. But some kinship organisations above the level of the nuclear or extended family (such as lineages and clans) in some contexts may constitute elements of civil society, and should be analyzed as such. The definition also generally excludes profit-oriented or capitalist corporations, although several comments are in order here. Certain types of firms, such as the media and non-profit enterprises, are often important elements of civil society. And where corporations and their CEOs combine in the form of business associations, these are normally regarded as a part of civil society.

More generally, civil society includes all manner of social organisations found between the household and the state, an apparatus composed of a complex of institutions such as governments, the judiciary, the legislature, the armed forces and any other institution used to project the power to determine who gets what in society ('the authoritative allocation of society's productive resources'). Thus, the United Nations Development Programme (UNDP), the World Bank and other such agencies of international development adopted the term 'civil society' in its discourse precisely because it was so inclusive, including within its scope the 'private sector' (basically capitalist or multinational corporations governed by the logic of capital accumulation or profit-making). The incorporation of the 'private sector' into the development process was a fundamental aim of the UNDP, the World Bank, the International 
Monetary Fund and other such/international financial institutions' that dominate the development process and lead the fight against world poverty (MITLIN, 1998) ${ }^{5}$.

It could be argued that clandestine organisations or paramilitary organisations such as... in Colombia should be excluded because they do not operate in full public view. However, given that (i) in some contexts (for example, Colombia) they are important in state-society relations; (ii) clandestine groups can be transformed into associations that operate in the open; (iii) that some of them are forced to operate clandestinely by government bans; and (iv) in some discourses they are alluded to if not defined, they should probably be included.

Political parties present some conceptual difficulty. They are sometimes seen, at least in the 'liberal' tradition, as part of civil society. But there are several problems here. First, parties usually serve as bridges between civil society and government. They straddle the division between the two in ways that may undermine their loyalty and responsiveness to civil society. And since they often exercise state power and act on the imperatives of government, many of them are not strictly speaking representative of civil society. They can also be part of or become involved in government efforts to control, repress, intimidate, marginalize, or co-opt civil society in ways that damage it. Second, some parties are so entirely the creations (and/ or the creators) of governments or states (or they are so dependent upon governments) that they scarcely qualify as elements or representatives of civil society.

Finally, civil society or nongovernmental organisations (NGOs) are generally issue-oriented in their actions rather than class-based, raising questions about whether or not to include social movements. Social movements are generally concerned with disputing state Powerwith bringing about a change in government policies or, like political parties, in governments themselves (albeit in a different way-mobilizing the forces of opposition and resistance rather than participating in elections). In contrast to social movements (see discussion below), civil society in the form of NGOs (or in the voluntary sector) are generally concerned with more specific interest groups and issues such as the environment, the discrimination or empowerment of women, human rights, development education, disaster or other forms of relief or emergency aid, or poverty alleviation. Some analysts see in NGOs a very different form of organisation from classbased organisations such as social movements whose raison d'etre and objectives are much moiré 'diffuse'-not issue-oriented as much as concerned to bring about a change in government policy or in the class system behind it.

The type of organisation encompassed by the term 'civil society' is not the only issue. Social organisations generally take four fundamental forms: (i) associations or associational (sharing an organisational objective); (ii) communities or community-based (held together by social bonds and a culture of solidarity, a shared sense of belonging); (iii) class-based organisations (defined by a pursuit of class interest or political power); and (iv) networks (informal or formal, social relations horizontal in form]. For convenience, civil society analysis normally or often focuses on the first two types, treating the third as 'economic' (for example, multinational corporate forms of capitalist enterprise) or 'political' (for example, political parties) rather than 'social' forms of organisation. As for social networks they can lead to or be combined with both associational or community-type social relationships among the units, but what characterises them is horizontality and, in a community context, opportunities for building 'social capital' based on shared norms of reciprocity and a culture of solidarity. In this typological context, social organisations can be numerous and diverse, with overlapping memberships, referring to one of four ways of achieving shared purposes and common objectives.

The size and strength of 'civil society' in this organisational context is normally measured in terms of the number of 'active' formally constituted social organisations, the density of the resulting social fabric, and the networks that bring people together to act collectively to achieve or in pursuit of their shared goals and common objectives. A major factor here is the degree to which people rely on governments or the state, as opposed to their own social organisations and networks, to achieve these goals and objectives. Thus, from the 1950s to the 1950s, with the growth of the welfare and development state (in which governments assumed primary 
responsibility for both welfare and development) many societies increased their reliance on the government, with a corresponding weakening or aborted development of 'civil society'. In the 1980s, in a new context defined by the insertion of many countries into the system of global capitalism, there was a general retreat of the state, resulting in a corresponding growth and strengthening of civil society in societies that participated in this process ${ }^{6}$.

The emergence, strengthening and role of civil society organisations in this new contextand of course the process has been variable, advancing in some places more than others-is discussed below.

\section{Civil society in historic and the current context: Setting the Stage}

Social change can be analysed in terms of three dynamic factors; agency (the strategies pursued and actions taken by diverse organisations and individuals), structure (the institutionalized practices that shape or limit action) and context (the specific 'situation' or historic conjuncture of objectively given and subjectively experienced 'conditions' of social or political action). In regard to the emergence, growth and strengthening of civil society in the 1980s there are at least five contextual elements. Each of these elements takes the form of a variable but persistent trend, which can be analysed in terms of three critical dimensions: (i) the actions or policies that provide the driving forces of the social change process; (ii) the social, economic and political impacts of these actions and policies; and (iii) the strategic and political responses to these impacts by different social groups and classes, according to their location in the social structure and the broader system of global capitalism.

- Globalization ${ }^{7}$ : The process of globalization-the integration of countries across the world into a new world order in which the forces of economic and political 'freedom' (free trade, the market, the private sector, democracy, etc. are able and allowed to flourish-has had an ambiguous impact on civil society organisations. On the one hand, like other domestic agencies such as the state and private business, the invasive pressures of global markets often compromise their autonomy or sovereignty. On the other hand, globalizationparticularly in terms of freer flows of information and communication across national boundaries-has fostered the spread of 'transnational communities' and an incipient global civil society (see discussion below).

- Democratization/political liberalization: The spread of democratization in recent years has changed the political and institutional environment in which civil society organisations operate. In some cases civil society has been the locus of active opposition to authoritarian governments, providing a breeding ground for alternative, participatory or 'democratic' forms of political organisation-and governance. In other cases civil society is marginalized or weakened through state repression or withdrawal from active engagement in politics. Civil society in this context may constitute the locus in which civic values and norms of democratic engagement are nurtured, although greater political freedom can be exploited by self-interested groups to advance narrow, self-interested agendas that can so exacerbate political conflict as to undermine 'good', that is, 'democratic' governance.

- Reform of political structures/political liberalization: Democratization has often entailed the reform of existing political structures (democratizing the relation between the state and society) or the creation of new, more democratic structures. This can involve constitutional redesign, the devolution of power to local governments (decentralization), and formal arrangements to widen public access to policy-making and/or ensuring greater accountability and transparency. These political developments can provide space for civil society organisations to engage in new activities, strengthen their interaction with politicians and public officials, and involve larger number of people in active politics and government affairs.

- Institutional rebalancing in the interest of 'good governance': Challenges to the fiscal capacity of states $^{8}$, and doubts about their institutional efficacy and political character, have led to efforts to 'rebalance' systems of social welfare provision in favour of the market (the 'private 
sector') and civil society organisations. This has sometimes meant that civic organisations have taken on responsibilities for providing social goods and public services to their own constituencies and wider communities, requiring a rethink of their organisational structures, financial base and relations with government. More generally it has meant a reduced role of governments in maintaining political order and an enlarged role of civil society in this regard ${ }^{9}$.

- Privatization ${ }^{10}$ : The rapid economic growth experienced by many developing countries in the 1950s, the 1960s and 1970s in large measure was fuelled by growth of the public sector and a policy of nationalization-taking over from the 'private sector' (the multinational corporations, that is), and buying out firms, in the strategic sectors of the economy (oil production, for example). In the 1980s this policy was reversed in a new policy of privatization: turning over state enterprises to private enterprise under the guise of a presumed 'efficiency'. This new policy allowed capitalist corporations-often multinational in form and foreign-owned-to acquire these enterprises at bargainbasement prices, often greatly enriching their new owners ${ }^{11}$.

- Decentralization ${ }^{12}$ : Until 1980 or so political scientists (and economists, for that matter) in both liberal and conservative traditions generally subscribed to the notion that democracy was not necessarily conducive to economic development-that authoritarian regimes provided a better agency. In the 1980s, however, there was a sea-change in this idea, leading to the contrary notion that economic liberalisation would lead to political liberalisation or vice versa. This idea, together with the ideology of a minimalist state, led to widespread calls for 'democracy' and 'good governance' in the form of a more participatory form of politics and development. To establish the required institutional framework for these developments (and, at the same time, to reduce fiscal pressures on governments) the World Bank, on the basis of lessons drawn from Chile, argued the need for a policy of administrative decentralization, with a partnership approach to both local governments and civil society (BLAIR, 1995; RONDINELLI, McCULLOUGH and JOHNSON, 1989), UNDP. 1996; WORLD BANK, 1994).

- Economic liberalization: The major improvement in socioeconomic conditions characteristic of the 1950s and 1960s was based on the active agency of governments in redistributing for the common benefit market-generated wealth and incomes. In the developing countries of the global south, it was also based on protectionism, a policy designed to protect the fledgling industry from the forces of the world market, to give domestic companies a chance to grow by placing restrictions on foreign investment and the operations of the multinational corporations in their countries. Under the 'new economic model' of freemarket capitalism and neoliberal globalization this policy was reversed.

Economic liberalization has had a number of contradictory consequences for civil society. In some contexts it weakened predatory state structures and limit the scope for 'rent-seeking behaviour' ${ }^{13}$ by political and bureaucratic elites. It is clear that some groups are better placed than others to exploit the opportunities created by liberalization for advancing their own economic agendas, and organisations representing their interests can wield considerable influence over decision-making. The removal of price controls and other restrictions on economic activity are often accompanied by the growth of the informal economy, and the emergence of a dense network of groups and associations geared toward the advancement of collective economic interests. The removal of safetynets and reduction in government welfare spending gives rise to a proliferation of selfhelp groups and development associations whose mandate is to provide relief and services to people marginalized or impoverished by market reforms.

- Deregulation. State-led development is predicated on government regulation of private economic activity and markets in the public interest. However, from the perspective of firms concerned with maximising their profit-making opportunities this policy is viewed as an intolerable attack on freedom that inevitably results in 'inefficiency' and a distortion of market forces which, if unhindered, produces an optimal distribution of society's productive resources and incomes. In the 1980s, the perceived 'failure' of the state in the 
form of a widespread fiscal crisis (an inability to finance from government revenues costly social and development programs) crated political conditions for a reversal of this regulatory approach and the implementation of a deregulation policy.

\section{The economic and political dynamics of development and civil society}

Development is understood as a combination of improvements in the quality of people's lives-marked by a reduction or alleviation of poverty, an increased capacity to meet the basic needs of society's members and the sustainability of livelihoods and the empowerment-and the changes in institutionalised practices or 'structures' needed to bring about these improvements, the idea of development can be traced back to an 18th century project based on the idea of progress-of the possibility of and necessity for a better form of society characterised by freedom from tyranny, superstition and poverty, and social equality. However, it was reinvented, as it were, in 1948, in the context of [i] a post war world order based on the IMF, the World Bank and GATT, a free trade negotiating forum; [ii] an emerging eastwest conflict and cold war; and [iii] a national independence struggle by countries seeking to escape the yoke of European colonialism... and imperial power-Pax Britannica in the prewar and Pax Americana in the new post war context.

In this context, international cooperation for development-foreign aid in the official parlance-nation-building and capitalist industrialization and modernisation was designed as a means of ensuring that those countries emerging from colonialism would not fall prey to the lure of communism. The active agent of this process was the state in the form of policies and programs designed to (i) increase the rate of savings and productive investment [capital accumulation] [ii] invest these savings in new technology and industrial expansion] modernisation and industrialization] [iii] the social redistribution of some market-generated incomes, by means of progressive taxation, to social and development programs; and [iv[technical and financial assistance to emerging developing countries in the south.

From 1948, at the outset of his development process signalled by Harry Truman's 4Point Program (of development assistance), to the early 1970s, when the world capitalist system ran out of steam and entered a period of prolonged crisis, these policies and this stateled form of development generated an unprecedented period of economic growth and societal transformation [industrialization and modernisation]. Growth rates in this period, fuelled by rising wages and a rapid growth of the domestic market as well as international trade, exceeded by a factor of two the economic growth rates of previous decades, resulting in an incremental but steady improvement in the physical quality of life and the social conditions of health, education and welfare. Historians have dubbed these advances as the 'golden age of capitalism' (MARGLIN and SCHOR, 1990).

In 1973, at the height of an apparent crisis of overproduction, characterised by cutthroat competition, saturated markets and stagnation, inflation, sluggish productivity and falling profits, the capitalist class in the rich countries in the OECD, the CEOs of its enterprises, and governments in their employ or service, abandoned the system that had served them so well. Or, to be more precise, they sought to renovate this system, to resolve the crisis of capitalist production by (i) changing the relationship of capital to labour, advancing the former and weakening the latter ${ }^{14}$; (ii) the incorporation of new production technologies and a new regime of accumulation and labour regulation [postfordism]; the relocation overseas of labourintensive lines of industrial production, creating hereby, unwittingly it might be added, a new international division of labour; and, above all [iv] a process of structural adjustment in macroeconomic policy and globalization, generating in the process, intentionally, a 'new world order' The policies that facilitated this process generated epoch-defining changes, a seismic shift in international relations-a new world order in which the forces of freedom and democracy can prevail.

By the end of the 1980s, most countries had been brought into line with the 'new world order' of neoliberal globalization and free market capitalism. In the 1970s, in the first phase 
of neoliberal experiments the implementing agency was a series of military regimes in the southern cone of south America-in Chile, Argentina and Uruguay Veltmeyer and Petras, 1997, 2000). When these experiments with neoliberal policies crashed and burned in the early 1980s, a new crop of liberal democratic regimes, forced into line by the realities of a regionwide debt crisis of historic proportions, initiated a second round of neoliberal policy reforms. They did so with the assistance of na emerging civil society in the so-called third sector of non-profit, voluntary associations and nongovernmental organisations. These organisations, formed in response to a generalised retreat of many governments from their erstwhile primary responsibility for economic development and social welfare, were enlisted by International Financial Institutions (IFIs) such as the World Bank and the international community of development associations and aid donors to mediate with the poor, to assist them in their self-development efforts in return for an acceptance of their policy advice (CARROLL, 1992).

The scholarly literature on these issues is divided. Some see the development NGOs as 'saviours', rescuing the capitalism system from itself (CARROTHERS, 1999; HAYDEN 2002; KAMAT, 2003). These authors emphasise the role of NGOs not so much in delivering economic assistance (micro-development projects or poverty alleviation funds) but in democracy promotion, which, Ottaway (2003: vi) notes, is a 'new activity in which the aid agencies and NGOs [originally] embarked [upon] with some trepidation and misgivings' but that in the early 1990s ' [came] of age.' Others, however, see them as stalking horses for global capitalism and neoliberalism, Trojan horses to facilitate the entry of foreign investment and the domestic operations of multinational corporations-and, in the process, to help them realise the imperial dream of some for world domination (PETRAS and VELTMEYER, 2001, 2005, 2007).

\section{NGOs: catalysts of development, saviours or agents of outside interests?}

The major expression of civil society in the 1980s was the 'voluntary private association' or 'nongovernmental organisation', formed in what at the time was defined as the 'third sector' (vs. the 'private sector', composed of profit-making economic enterprises, and the 'public sector', referring here to organisations and enterprises set up by the government).

At the beginning of the decade there were relatively few such organisations, most of them organised as voluntary associations to provide poverty relief or to assist communities in their adaptation to the forces of change. By the end of the decade, however, these nongovernmental third sector organisations had mushroomed, responding as they did to the vacuum left by the retreating, assuming responsibilities hitherto given to governments. It is estimated that by 1990s there were literally tens of thousands of developmental NGOs, organised to assist poor communities in the quest for selfdevelopment, as well as NGOs formed in the struggle against the violation of human rights, environmental protection and other such issues of concern to the urban middle class. Political sociologists, armed with a postmodern political imagination, saw this development as the emergence of 'new social movements', concerned with an array of diverse issues (ESCOBAR and ALVAREZ, 1992) rather than state power and transformative social change. Traditional social movements b y contrast were viewed as class-based and concerned with transformative social change.

NGOs were enlisted by the international financial institutions such as the World Bank and the governmental and intergovernmental organisation as strategic partners in the war against poverty, to act as intermediaries between the providers of financial and technical assistance and the poor communities ravaged by the forces of modernization and change, and abandoned by their governments (at the behest of these 'overseas development associations'). 'Development' here was conceived within the optics of a new paradigm that valorised 'popular participation' and grassroots self-development that is initiated 'from below'from within civil society.

To create an appropriate institutional framework for such an 'alternative' form of development, the IFIs and the development associations engaged in 'international cooperation' promoted a policy of administrative decentralization, which in short order was incorporated 
into the NEM, together with the structural reforms mandated by this model as the cost of admission into the new world order: privatization of public enterprises, financial and trade liberalization, deregulation of markets and private economic activity, and democratizationof both the state-civil society relation and the political regime, replacing authoritarian rule with liberal democracy and the rule of law.

The NGOs in this context were recruited not only to mediate between the aid donors and the poor communities but to carry into the localities and communities of the poor the gospel of capitalism and democracy, the virtues of private enterprise and reform. By the end of the decade and into the 1990s, the marriage between economic and political liberalization had been consummated in many countries with the NGOs acting as midwife. In the process the NGOs helped dampen the fires of revolutionary ferment among the rural poor, who were encouraged to turn away from the confrontational politics of class-based organisations and the anti-systemic social movements.

There are at least two fundamental theoretical perspectives on these NGOs in this development context. One group of scholars view them essentially as saviours, catalysts of a grassroots virtuous form of development that is initiated from within civil society, and is participatory, empowering of women and the poor, equitable and socially inclusive, human in form and scale, and sustainable in terms of both the environment and livelihoods.

Other scholars, however, take a less sanguine and very different view of these development NGOs, viewing many of them not as catalysts of development but as the stalking horse of neoliberal globalization, a Trojan Horse for global capitalism-the paid, if often unwitting, agents of US imperialism (WALLACE, 2003). Proponents of this view argue in effect that NGOs do not serve the interests of the rural poor as much as the interests of their masters, the new 'rulers of the world', a transnational capitalist class composed of corporate CEOs, financiers and major investors-and the guardians of the new world order and its billionaire beneficiaries.

The argument of these scholars is that NGOs are enlisted as front-line soldiers in the war on poverty, in the localities and communities of the poor, to provide what assistance (poverty alleviation funds) might be available and, in the process, instill respect for the virtues of capitalism and democracy. The war on poverty, it is argued, is simply a charade $t$ mask the real agenda: to create a world safe for capital-to facilitate the entry of foreign investment and the multinational corporations. The implicit mandate of these NGO, it is also argued, is to help turn the rural poor away from joining the social movements and a confrontational politics of direct action against government policy; to seek change and improvements in their lives not by challenging the structure of economic and political power but rather to turn inwards-to change not the system but themselves (empowering them to act on their own behalf); to seek improvements and change in the local spaces of the power structure rather than challenging this power. That is, NGOs are seen as unwitting agents of outside forces and interests, helping to depoliticise the poor in their struggle for change.

\section{The emergence of a global civil society: The political dynamics of antiglobalization}

"Globalization policies have... increased inequality between and within nations" (IFG website).

"Globalization raises incomes, and the poor participate fully" (The Economist).

"It is evident that globalization produces a few winners and makes most of us losers" (PETER MARTIN, former Prime Minister Canada).

"Globalisation is not politically, environmentally or morally sustainable. It is civilizationally unacceptable" (KARI LEVITT, CASID Address, 2001).

The measures associated with neoliberal policies in the 1990s led to a dramatic increase in social inequalities-disparities in the global and intra-regional social distribution of wealth and poverty, marked by an extension and deepening of existing poverty, and a social polarization between the rich and the poor. In the 1990s this 'inequality predicament' (as the 
United Nations, in a 2005 study, defines this 'development') assumed grotesque proportions. In a world of spreading poverty neoliberal policies sprouted a new class of multi-billionaires, the clear 'winners' of globalization. In 1996, according to Forbes magazine, there were 793 of them but within a year the number of multi-billionaires had grown to 946. In the US there were just 13 billionaires in 1985. Today, according to Forbes magazine, there are 415, representing the top. $01 \%$ of the population who have managed to appropriate $25 \%$ of all the wealth produced in the US over the past two decades. In 2005, neoliberal policies created 227,000 millionaires. The wealth of these millionaires was $\$ 30$ trillion, more than the combined GDP of China, Brazil, Russia and the EU (HARRIS, 2007) ${ }^{15}$.

The UNDP $(1996,2001)$ estimates that a roomful of these superrich, fewer than 300 , roomful of just 358 individuals, dispose of the equivalent income of $45 \%$ of the world's poorest (3.5 billion), who have to subsist on less tha $\$ 2$ a day, a statistic that the UNDP understandably finds 'grotesque'. The total wealth of the world's richest individuals (Forbes list of billionaires), representing a one hundred millionth of the population, increased their wealth this year by $35 \%$ to $3.5 \$$ trillion-more than the total wealth of the world's poor. In other words, poverty is the product of the same policies and the same system that generated a very unevenly distributed wealth: wealth for the few, the 'winners' of globalization, and poverty and immiseration for the many, the 'losers'.

Neoliberal policies that the World Bank describes as 'pro-growth' and 'pro-poor' has produced not only mass poverty but also made some individuals incredibly rich-the Forbes magazine's list of billionaires-up from 793 in 2006 to 946 this year. However, the 'losers' in the global competition for wealth-or the victims, to be more precise-have not been passive in their response to neoliberal globalization. They have responded by forming and joining a social movement of opposition to these policies., resistance against the dynamics of globalizing capital. This movement has taken diverse forms both in the north and the south. In the global south (societies in the developing world) the movement is based on, and by and large has been led by, the indigenous communities and peasant farmers whose physical quality of life, livelihoods and communities have been the major targets and victims of 'globalization'. The working class, in both its waged/formal and unwaged/informal forms are also victims. But the capacity of the workers to wage a defensive or offensive struggle has been dramatically diminished over the pas two decades, turning over leadership of the popular movement to the landless rural workers, peasant farmers and indigenous communities.

As for the north (the rich industrial societies in the OECD-mostly in Europe, North America), the antiglobalization movement is centred in the urban centres, based on the middle class in these centres, and has taken the form of antiglobalization-opposition to the agenda of corporate capital. Unlike the situation in the south, where antiglobalization is directed against governments and government policies, the antiglobalization movement in the north (see Insert D) has taken and takes the form of counter-summits to the G8 summits, protests organised at the periodic gatherings of the WTO and other such organisations of global capital, and, perhaps more importantly, in the form of a World Social forum, which brings together annually thousands of antiglobalization activists, representing hundreds of civil society organisations, to discuss problems and debate strategy. This antiglobalization movement is not against globalization as such but against its neoliberal form. In this context, antiglobalization is a movement formed in the search for 'another world', a more ethical form of globalization, a more equitable and socially inclusive and participatory form of development-an alternative to neoliberal globalization, capitalism and imperialism.

In the Spring of 2007, the UK Ministry of Defence published a report (Global Strategic Trends 2007-2036) warning that the whole system of global capitalism, and with it the new world order, could well be brought down by the mounting forces of opposition and resistance. The Report argues that the excessive inequalities (widening divide), will likely lead to a 'resurgence of not only anti-capitalist ideologies... but also to populism and the revival of Marxism' $(2007$, p. 3). The Ministry is particularly concerned that the widening global divide in wealth and income-what the UN has termed 'the inequality predicament'-has spawned a 
mass global justice movement, a broad movement that threaten to unite the most diverse forces of resistance and opposition to neoliberal globalization.

The meaning of this antiglobalization movement, and the growth of a transnational civil society committed to the search for 'another world', is subject to continuing debate. Some see it as a palliative. Others see it as the salvation of humanity on a fast road to selfdestruction. But there is no question that it might very well scuttle the best-laid plans of the new world order architects for imperial rule.

\section{Civil society and local development}

The search for a new development paradigm can be traced back to the1970s but it acquired a particular vigour and a very broad scope in the 1980s with the turn towards a 'new economic model' prioritizing the free market. The proponents of a new paradigm visualized development as community-based and/or localized, reaching beyond both the state and the market into the localities and communities of the rural poor. The aim of theorists and practitioners in this context was to advance development that was human in form and scale, sustainable in terms of the environment and livelihoods, socially inclusive and equitable and participatory-initiated 'from below' and 'from within' civil society as opposed to 'from above' (government) and 'the outside' (international assistance).

To some extent this paradigm shift has to with a longstanding concern to give development a more distinct social dimension. From the beginnings the study of development was dominated by economics and economists. In this study, the 'social' and the 'political' were usually abstracted from analysis, treated as 'externalities' in a process conceived of in strictly economic terms. But within the framework of the 'new paradigm' the 'social' was given more weight, even in the analysis of 'capital', the sum total of society's wealth-begetting wealth. Economists had formulated the theory that economic development was based on capital accumulation, and that it was advanced by means of an induced increase in the rate of national savings and productive investment of these savings.

However, 'capital' in this theory was defined purely in economic terms-basically money invested the design of new technology and the purchase of labourpower, and the transformation of natural resources into commodities or tradeable goods. Within the framework of the new paradigm, however, society's productive assets ('capital') was also conceived of in social terms, that is, as 'the norms, institutions and organisations that promote trust and cooperation among persons in communities and in the wider society'. Initially advanced by several sociologists (notably James Coleman and Pierre Bourdeau) this notion of 'social capital' was elaborated by leading development economists such as Robert Chambers (1983) and Robert Putnam (1993, 2000, 2002).

This was in the 1980s. In the 1990s this concept of 'social capital' took on a new life, supported and advanced by all manner of scholars, international organisations and policymakers in their development discourse. At issue in this discourse was an alternative way of conceiving, thinking about 'development' and fighting the war against world poverty (DURSTAN, 1999, p. 104) ${ }^{16}$. More specifically, the proponents of this new approach claimed that the accumulation of social capital based on norms of trust and reciprocal exchange, and a culture of social solidarity, can reduce 'transaction costs' (IFAD) ${ }^{17}$, produce public goods (North, 1990), facilitate the 'constitution (or strengthening) of sound civil societies' (Putnam, 2000), constitute the poor as 'social actors' and empower them to act on their own behalf. Above all, it was argued, as an asset that the poor have in abundance (their only asset, one could add), social capital promotes self-development of the poor in their localities and communities, alleviating the socioeconomic (and psychological) conditions of poverty.

The book by Robert Putnam, Making Democracy Work (1993), by some accounts, served as the catalyst for generating this interest in social capital as a research and policy tool ( ). But the rapid spread and ubiquity of this notion of social capital in academe, and its wide-ranging applications in research, policy-formulation and practice, has given rise to serious questioning 
and several concerns.

First, what is striking about social capital is not only the extent of its influence but also its ready and enthusiastic acceptance by both scholars and policy-makers. These features are aptly captured by the World Bank's notion of social capital as 'the glue that holds society together', as the 'missing link' in an analysis of the development process (de la ROCHA, 1994; HARRIS and de RENZIO, 1997; SOLOW, 2000).

Secondly, despite the plethora of survey articles that litters the intellectual landscape, the concept is notoriously difficult to define. Most recent contributions to the literature acknowledge this before adding a definition of their own to suit their own purpose (see discussion on this in Fine, 2001). The elusiveness and ambiguity of 'social capital' is reflected in the suggestion that it is merely a metaphor or a heuristic device, and that, in regard to the World Bank's not atypical formulation, based on 'a vicious circle of tautological reasoning and without any basis in empirical fact (PORTES, 1998) ${ }^{18}$.

Thirdly, the concept of social capital is used to describe and explain virtually anything and everything from the networks formed by the poor, the sick, the criminal, and the corrupt to the social dynamics of the (dys)functional family, schooling, community development, work and organisation, democracy and governance, collective action, the intangible assets of the social economy, 'the analysis and promotion of peasant-level development', or, indeed, any aspect of social, cultural and economic activity across time and place-everything, it would seem, except the norms, institutions and social networks formed by those that constitute what John Pilger (2003), the Australian writer, documentary filmmaker and award-winning journalist, terms 'the new rulers of the world', the class that runs the global economy and makes up its rules.

The final concern about social capital is in regard to ideology and politics. In this connection, what appears to be is missing in the analysis informed by the notion of social capital is any concern with economic and political power. The concept of social capital appears to serve analysts and policy-makers in the same way that post-modern social theory serves analysis: as a means of eluding in thought what for most people is all tôo real-the dynamic workings of the world capitalist system. The dynamic power relations that determine life for most people are inverted: what is essentially a class struggle over the allocation of society's productive resources, a matter of state and economic power, is transmuted into 'empowerment' - a sense of capacitation, a feeling of power gained by individuals through participating in decisions (such as how to spend the poverty alleviation funds that come their way) that affect their livelihood and an improvement in the physical quality of their life. The point is that this empowerment means changing oneself (how one feels about one's self) rather than the system and its structure of power relations.

Another form of this criticism is that the concept of social capital, in its use as a research and policy tool, is ideologically all too convenient for the powerful as well as politically demobilising. Harriss's (2001) argument and that of others in this connection makes three points.

One is that in making people responsible for their own development falsely implies that they are responsible for their problems, such as poverty, drawing attention away from the operating structures of the economic and social system. In its broad focus on the dynamics of 'civil society', social capital ignores (abstracts from analysis) the dynamics associated with the formal structures and institutions of society's political economy, particularly that of state power.

A second criticism is that in the way that it is used the concept of social capital has a demobilising effect regarding social transformation or radical change. Local development built on the basis of social capital entails limited improvements with even more limited or no changes in the existing distribution of (or access to) 'capital' in the form of land and related resources, or money in the form of investment capital or credit. Access to and control over these 'resources'-arguably the major factors of economic development-remain in the hands (and institutions) of the rich and powerful while the poor and powerless are encouraged to 
exploit their own rather limited resources and to do so without challenging the structure of economic (and political) power. Some critics in this context regard social capital and empowerment as illusory, implying not so much false assumptions or 'unrealistic expectations'the most common criticism-as a trick used by the rich and powerful to keep the have-nots at bay.

\section{Notas}

1 'Good governance' (see the multiple bibliographic reference to various World Bank and UNDP reports) is generally understood to mean a broad array of practices which maximize the common/public good. More specifically, the term denotes to a relation between social organisations and government that conforms to the following 'democratic' principles: transparency, effectiveness, openness, responsiveness, and accountability; the rule of law, acceptance of diversity and pluralism, and social inclusiveness.

2 The term 'civil society' dates back to the 18th Century French and Scottish enlightenment, when 'philosophers' and like. Ferguson invented the term to distinguish more clearly between 'society' and 'government' in their writings about 'progress'. The idea of 'progress' (the possibility of creating a better alternative form of society), and the notion of 'civil society' was also used in the early nineteenth centuries by philosophers such as Hegel and his nemesis (and later social scientist), Karl Marx. However, the term 'civil society' virtually disappeared from social scientific discourse; it was resurrected in the 1980 s by a generation of social scientists concerned once again with creating a new and better form of society- liberated from soviet authoritarianism this time as opposed to the class-based and elitist monarchy of the ancien regime).

3 'Liberal' in academic discourse has both an ideological and theoretical centre of reference. As 'ideology' (belief in ideas used to promote action) liberalism is defined by the notion, and associated values, of the free individual, and the belief in the need for economic and social progress (slow incremental change or reform) in the direction of individual freedom. As 'theory' it is associated with the notion of homoeconomicus-that economic interactions among individuals in the marketplace is based on the rational calculus, by each individual, of self-interest. This notion is central to both classical and neoclassical economic theory-and to the policies derived from this theory.

${ }^{4}$ For a more detailed discussion of these definitional issues, see Gordon White, "Civil Society, Democratization and Development: Clearing the Analytical Ground," Democratization (AUTUMN, 1994), p. 375-90.

${ }^{5}$ According to Mitlin (1998), the 'community' of international development associations' (ODAs) shifted from a 'third sector' discourse to a discourse on 'civil society' in the early 1990s as part of an agenda, orchestrated by the UNDP, to incorporate the 'private sector' into the development process. On this agenda see///. The problem with the notion of a 'third sector' was that because 'private sector organisations such as multinational corporations pursued a logic of capital accumulation (profit-making) they were a large part of 'the problem' (underdevelopment and poverty) and could not be part of 'the solution' (development). The advantages of 'civil society' as a concept is that it is more organisationally inclusive, allowing the UNDP and other ODAs and the IFIs to seek to incorporate the private sector in to the development process.

${ }^{6}$ The early history of the community development movement in the 1950s and the 1960s signified the emergence of a 'pluralist democratic culture' in many developing countries as well as a concern for local development within the framework of liberal reforms of national policy. But the dominant trend was for economic and political development based on the agency of the central government and the state. However, in the new policy environment of 'structural' free market reform this incipient democratic culture was cultivated by the return of civilian constitutional rule, and, at another level, by widespread policies of privatization and decentralization. With the retreat of the state from the economy and its social (and developmental) responsibilities it was left to 'civil society' to pick up the slack - in the form of emergent self-help organisations of the urban poor and a myriad of community-based and nongovernmental organisations to deal with issues of social and economic development such as health, housing, food kitchens (comedores or communal dining halls), capacity building and self-employment. The emergence of a 'civil society' was a predominant feature of the 1980s.

${ }^{7}$ Globalization, presented as a particular form of international economic integration into the global economy, the $\mathrm{NWO}$, is used to justify and legitimate policies [free trade, the free circulation of capital and the freedom of investment...) that have in fact been imposed by force on the colonies since the late 18th century; policies that in the contemporary context, given a neoliberal twist-downsizing of the state, privatisation, deregulation, liberalisaton, etc.

${ }^{8}$ In fact, the retreat of the state from the economy, and from its primary responsibility for both welfare and development, was made possible politically by the 'fiscal crisis' experienced by many governments (incapacity to finance its costly social and development programs) and an associated perceived (by neoconservative politicians and policy makers) 'state failure'.

${ }^{9}$ The institution of 'good governance' implies a democratic regime in which the responsibility for human security and political order is not restricted to the government and other institutions of the state but is widely shared by different civil society organisations (BID, 1996, 2000; OECD, 1997; UNDP, 1996; World Bank, 1994).

${ }^{10}$ The conjunction of a retreating minimalist state and the exponential increase in community-based NGOs led to the conclusion that the phenomenon was analogous to 'the franchising of the state' (Kamat, 2003: 66). In this context both the donor agencies and the IFIs recommended the privatization of both economic activity and social services -a trend that in any case was already underway- and the allocation of ODA to community-based NGOs 
for the same programs. Under these conditions the community-based 'grassroots' NGOs proliferated as did the Northern NGOs anxious to occupy the spaces left by a retreating state.

${ }^{11}$ For example, Carlos Slim, a billionaire business magnate in Mexico, and now, according to Forbes, the richest man in the world, even more so than Bill Gates, 'purchased' Telecom, the country's lucrative state enterprise in the telecommunications sector.

${ }^{12}$ The early history of the community development movement in the 1950s and the 1960s entailed the emergence of a 'pluralist democratic culture' in many developing countries as well as a concern for local development within the framework of liberal reforms of national policy. But the dominant trend was for economic and political development based on the agency of the central government and the state. However, in the new policy environment of 'structural' free market reform this incipient democratic culture was cultivated by the return of civilian constitutional rule, and, at another level, by widespread policies of privatization and decentralization. With the retreat of the state from the economy and its social (and developmental) responsibilities it was left to 'civil society' to pick up the slack-in the form of emergent self-help organisations of the urban poor and a myriad of community-based and nongovernmental organisations to deal with issues of social and economic development such as health, housing, food kitchens (comedores or communal dining halls), capacity building and selfemployment. The formation of this 'civil society' was a predominant feature of the 1980s.

13 'Rent-seeking' refers to use of the state by members of the political class as a means of self-enrichment, exacting a 'rent' payment from the public (taxpayers) by means of their control of the means of public administration. This notion of 'rent-seeking' has been elaborated by proponents of the 'new political economy', a school of thought committed to a neoclassical theory of the free market (as opposed to the state) as the most efficient means of allocating society's productive resources. In terms of policy and ideology this approach is defined and understood as 'neoliberalism'.

${ }^{14}$ Capital is advanced by increasing the rate of savings and investment-increasing the share of national income available for investment relative to household consumption; reducing the share of wages in national income $b$ y com pressing the value of these wages and weakening the capacity of workers to negotiate collective agreements for higher wages and working conditions. The 1960s and 1979s witnessed a general increase in the power of organised labour, reflected in steady increases in the value of the wage, which was pegged to productivity gains. 1968 represented a highpoint in the power of organised labour in the struggle against capital-the last great postwar labour offensive in the struggle for higher wages and better working conditions (DAVIS, 1984). In 1973, in the midst of a system-wide production crisis, capital initiated a counteroffensive, which, by and large was successful, as indicated by a subsequent relative decline in the share of wages in national in come and a decline in the value of the average wage. On this historic struggle see Davis (1984).

${ }^{15}$ Petras (2007) argues that Bill Gates and others who made their fortunes via technical innovations or wealth/jobgenerating industries or services, were in a distinct minority. The vast majority of these billionaires used the money of others, and speculation to build their fortunes. Many of them, as in Russia, built their personal fortunes by looting public assets, pillaging the state's accumulated assets, stealing and speculative investment in real estate and commodity trading-in construction, telecommunications, chemicals, real estate, agriculture, vodka, foods, land, media, automobiles, airlines.

${ }^{16}$ For a review of the dynamics of this shift towards 'another development' see, inter alia, Schuurman (1993 and PARPART and VELTMEYER (2004). The contribution made by the school of institutional economics (NORTH, 1990; PUTNAM, 1993) to this approach consists precisely in the concept of social capital as the source of a culture of cooperativism, solidarity and civicism, and the theory that this culture, embodied in the interpersonal links that make up the informal institutions within social organisations, has economic payoffs in the form of 'public goods'.

${ }^{17}$ IFAD (2002) has learned that 'strengthening local social capital ensures the sustainability of rural development initiatives by reducing transaction costs in the factor and product markets.'The development of social capital, notes IFAD, 'is particularly important for unemployed landless farmers and rural workers'.

${ }^{18}$ The World Bank's economic logic flows from institutional economics and its concept of social capital, articulated by Putnam (1993) and North (1990), as the source of a culture of cooperation and civism. As Porter (1998) points out the idea that social capital, embodied in norms of reciprocity and relations of solidarity, give rise to cooperation and civism so that if there is civism there will be social capital, is tautological to the extreme. Not only is the World Bank's reasoning hopelessly circular it is predicated on the unquestioned assumption that lies at the root of neoclassical economics, namely that allowing individuals in their economic exchanges and transactions to pursue their self-interest will somehow contribute to the common good. Thus the World Bank continues to persistently argue, against all sorts of empirical evidence, that a system of free market capitalism based on economic freedom and geared to private profit, like the policies that result ion this system, is good for the poor.

\section{References}

ANNAN, Kofi. The Quiet Revolution. Global Governance, 4 (2), p. 123-38, 1998.

ATAL, Yogesh \& YEN, Else (eds.). Poverty and Participation in Civil Society. Proceedings of A UNESCO/CROP Round Table, World Summit for Social Development. Copenhagen: Denmark, March, 1995.

ATRIA, R.; SILES, M.; Arriagada, M.; ROBISON, L. \& WHITEFORD, S. (eds.). Social capital and poverty reduction in Latin America and the Caribbean: towards a new paradigm. Santiago: ECLAC, 2004.

BEBBINGTON, A., et al. The search for empowerment: social capital as Idea and practice at the World Bank. Kumarian Press, 2006.

INTERAÇÕES, Campo Grande, v. 9, n. 2 p. 229-243, jul./dez. 2008. 
BLAIR, H. Assessing Democratic Decentralization. A CDIE Concept Paper. Washington DC: USAID, 1995.

CAROTHERS, T. Aiding democracy abroad. Washington DC: Carnegie Endowment for International peace, 1999.

CARROLL, T. Intermediary NGOs. The supporting link in grassroots development. Kumarian Press, 1992.

CHAMBERS, R. Whose reality counts? London: IT Publications, 1997.

CHHOTRAY, V. The Negation of Politics in Participatory Development Projects, Kurnool, Andhra Pradesh. Development and Change, 36 (2), 2004.

COURT, J.; HYDEN, G. \& MEESE, K. Governance Performance: the Aggregate Picture. World Survey Discussion Paper. Tokyo: UNU, 2002.

DAVIS, M. The Political Economy of late-Imperial America. New Left Review. 143, Jan.-Feb., 1984.

DOMINGUEZ, J. \& LOWENTHAL, A. (eds.). Constructing Democratic Governance. Baltimore: John Hopkins University Press, 1996.

EDWARDS, M. (u.d.). Enthusiasts, tacticians and sceptics: the World Bank, civil Society and social capital. World Bank Social Capital website, 1984.

ESCOBAR, A. \& ALVAREZ, S. (eds.). The Making of social movements in Latin America:identity, strategy, and democracy. Boulder, CO: Westview Press, 1992.

FINE, Ben. Social Capital versus Social Theory: Political Economy and Social Science at the Turn of the Millennium. London and New York: Routledge, 2001.

FOLEY, M. W. \& EDWARDS, B. Is it time to Disinvest in Social Capital?. Journal of Public Policy, 19 (2), p. 141-73, 1999.

FOX, J. How does Civil Society Thicken? The political construction of social capital in rural México. World Development, 24 (6), 1996.

GROOTAERT, C. Social Capital: The Missing Link? Social Capital Initiative Working Paper, n. 3. Washington DC: The World Bank Social Development Family Environmentally and Socially Sustainable Development Network, 1998.

HARRISS, J. Depoliticising Development. The World Bank and Social Capital. New Delhi: Left Word Books, 2001.

HAYDEN, Robert. Dictatorships of Virtue. Harvard International Review, Summer, 2002.

HOLLOWAY, John. Change the world without taking power: The meaning of revolution today. London: Pluto Press, 2002.

HOOGHE, Marc \& STOLLE, Ditelin (eds.). Generating Social Capital: civil society and institutions in comparative perspective. NY: Palgrave, 2003.

HYDEN, G.; COURT, J. and MEESE, K. (2-3). Making Sense of Governance: the Need for involving Local Stakeholders. Development Dialogue. London: IDI.

JOSEPH, J. Democracy's social capital: civil society in a new era. Pretoria, South África. Available at: <http:// www.worldbank.org/poverty / acapital/ index.htm>. Access at: 15 Jan. 1998.

KAMAT, S. NGOs and the New Democracy: The False Saviours of International Development. Harvard International Review. Spring, 2003.

LEVITT, K. Development in Question. Keynote Address. Canadian Association for International Development Studies, Toronto, May 31, 2001.

MITLIN, D. The NGO Sector and its Role in Strengthening Civil Society and Securing Good Governance. In: Armanda Bernard, Henry Helmich and Percy, 1998.

LEHNING (eds.). Civil Society and International Development. Paris: OECD Development Centre.

MORTON, A. La Resurrección del Maíz: Some Aspects of Globalisation, Resistance and the Zapatista Question. Paper presented at the 42nd Annual Convention of the International Studies Association. Chicago, February 20-24, 2001.

NARAYAN, Deepa. Empowerment and Poverty Reduction: A Sourcebook. World Bank, Washington DC, 2002.

NASH, R., A. Hydson \& C. Luttrell. Mapping Political Context: A Toolkit for Civil Society Organisations. London:ODI, 2006. OTTAWAY, M. Democracy Challenged: The Rise of Semi-Authoritarianism. Washington DC: Carnegie Endowment for International Peace, 2003.

PATOMÄKI, H. \& T. Teivainen. A Possible World. Democratic Transformation of Global Institutions. London: Zed Books, 2004. PILGER, J. The New Rulers of the World. London: Verso, 2003.

PORTES, A. Social Capital: its Origins and Applications in Modern Sociology. Annual Review of Sociology, 24, p. 1-24, 1998. PUTNAM, R. D. Making Democracy Work. New Jersey: Princeton University Press, 1993.

RAO, V. Community Driven Development: A Brief Review of the Research. World Bank, Washington DC for Environment and Development, 2002. 
RICE, J. \& PRINCE, M. Civil Society and Community Capacity: Links Between Social Policy and Social Capital, 2000, p. 207-231. In: Changing Politics of Canadian Social Policy. Toronto: University of Toronto Press Inc.

RONDINELlI, D.; MCCUllOUGH, J. \& JOHNSON, W. Analyzing Decentralization Policies in Developing Countries: A Political Economy Framework. Development and Change, 20 (1), p. 57-87, 1989.

SOLOW, R. Notes on Social Capital and Economic Performance. In: Partha Dasgupta and Ismail Serageldin (eds.). Social Capital: A Multi-Faceted Perspective. Washington DC: World Bank, 2000.

SCHULLER, T. et al. eds. Social Capital: Critical Perspectives. Oxford University Press, 2000.

UNDP. Good Governance and Sustainable Human Development. Governance Policy Paper, 1996. Disponível em: <http:/ /magnet.undp.org/policy>.

UNDP. The Shrinking State: Governance and Sustainable Human Development. Policy Document. New York: UNDP, $1997 f$.

UNDP. The UNDP Role in Decentralisation and Local Governance. UNDP Evaluation Office, February, 2000.

UPHOF, N. Social Capital and Poverty Reduction, 1994 p. 105-132. in: R. et al. Atria, (Eds). Social Capital and Poverty Reduction in Latin America and the Caribbean: Towards a New Paradigm. Santiago: ECLAC, 2004.

WALLACE, T. NGO Dilemmas: Trojan Horses for Global Neoliberalism? Socialist Register 2004. London: Merlin Press, 2003.

WOOLCOCK M. \& D. Narayan, Social Capital: Implications for Development Theory, Research and Policy," The World Bank Research Observer, 15 (2), August, 2000.

WORLD BANK. Governance and Development. Washington, DC: World Bank, 1992.

WORLD BANK. Governance. The World Bank Experience. Washington DC: World Bank, 1994.

WORLD BANK. World Development Report 2000/2001: Attacking Poverty. New York: Oxford University Press, 2000.

WORLD BANK. Partnerships in Development: Progress in the Fight Against Poverty. Washington DC: World Bank, 2004. 